\title{
Prolonged fasting and the effects on biomarkers of inflammation and on adipokines in healthy lean men.
}

Citation for published version (APA):

van Herpen, N. A., Sell, H., Eckel, J., Schrauwen, P., \& Mensink, R. P. (2013). Prolonged fasting and the effects on biomarkers of inflammation and on adipokines in healthy lean men. Hormone and Metabolic Research, 45(5), 378-382. https://doi.org/10.1055/s-0032-1330015

Document status and date:

Published: 01/01/2013

DOI:

10.1055/s-0032-1330015

\section{Document license:}

Taverne

\section{Please check the document version of this publication:}

- A submitted manuscript is the version of the article upon submission and before peer-review. There can be important differences between the submitted version and the official published version of record.

People interested in the research are advised to contact the author for the final version of the publication, or visit the DOI to the publisher's website.

- The final author version and the galley proof are versions of the publication after peer review.

- The final published version features the final layout of the paper including the volume, issue and page numbers.

Link to publication

\footnotetext{
General rights rights.

- You may freely distribute the URL identifying the publication in the public portal. please follow below link for the End User Agreement:

www.umlib.nl/taverne-license

Take down policy

If you believe that this document breaches copyright please contact us at:

repository@maastrichtuniversity.nl

providing details and we will investigate your claim.
}

Copyright and moral rights for the publications made accessible in the public portal are retained by the authors and/or other copyright owners and it is a condition of accessing publications that users recognise and abide by the legal requirements associated with these

- Users may download and print one copy of any publication from the public portal for the purpose of private study or research.

- You may not further distribute the material or use it for any profit-making activity or commercial gain

If the publication is distributed under the terms of Article $25 \mathrm{fa}$ of the Dutch Copyright Act, indicated by the "Taverne" license above, 


\section{Prolonged Fasting and the Effects on Biomarkers of Inflammation and on Adipokines in Healthy Lean Men}

Authors

Affiliations

\author{
N. A. van Herpen ${ }^{1,2}$, H. Sell ${ }^{3}$, J. Eckel ${ }^{3}$, P. Schrauwen ${ }^{1,2}$, R. P. Mensink $k^{1,2}$
}

'Department of Human Biology, NUTRIM - School for Nutrition, Toxicology and Metabolism, Maastricht University Medical Center, Maastricht, The Netherlands

${ }^{2}$ TI Food and Nutrition, Wageningen, The Netherlands

${ }_{3}^{3}$ Paul Langerhans Group for Integrative Physiology, German Diabetes Center, Düsseldorf, Germany
Key words

free fatty acids

cytokines

adipokines

received 13.07.2012

accepted 25.10.2012

Bibliography

Dol http://dx.doi.org/

10.1055/s-0032-1330015

Published online:

December 12, 2012

Horm Metab Res 2013;

45: 378-382

(C) Georg Thieme Verlag KG

Stuttgart · New York

ISSN 0018-5043

Correspondence

R. P. Mensink

Department of Human Biology NUTRIM School for Nutrition,

Toxicology and Metabolism

Maastricht University Medical

Center

P.O. Box 616

6200 MD Maastricht

The Netherlands

Tel.: + 31/43/3881621

Fax: + 31/43/3670976

r.mensink@hb.unimaas.nl

\section{Abstract}

$\nabla$

Obesity and insulin resistance are associated with low-grade systemic inflammation, which is related to increased concentrations of plasma FFAs, glucose, or insulin. Prolonged fasting induces insulin resistance due to elevated plasma FFAs, but is not accompanied by hyperinsulinemia or hyperglycemia. This makes it possible to study effects of physiologically increased FFA concentrations on inflammatory markers, when insulin and glucose concentrations are not increased. In random order, 10 healthy young lean men (mean BMI: $22.8 \mathrm{~kg} / \mathrm{m}^{2}$ ) were fasted or fed in energy balance for $60 \mathrm{~h}$ with a 2 -week wash-out period. Subjects stayed in a respiration chamber during the $60-\mathrm{h}$ periods. Blood samples were taken after 12,36 , and $60 \mathrm{~h}$. Then, a hyperinsulinemic-euglycemic clamp was performed.

Fasting decreased insulin sensitivity by $45 \%$ and increased FFA concentrations 5-fold. Fasting did

\section{Introduction}

$\nabla$

Obese subjects have increased concentrations of free fatty acids (FFAs), which may explain the frequently observed associations between increased body fat content and insulin resistance. Indeed, increasing plasma FFA concentrations by lipid infusion causes insulin resistance [1]. However, increased plasma FFA concentrations are also related to other metabolic complications such as low-grade systemic inflammation, which on its turn may cause insulin resistance, hyperinsulinemia, and hyperglycemia [2-4]. Indeed, several studies have demonstrated that insulin resistance is associated with elevated levels of high-sensitive C-reactive protein (hs-CRP) and interleukin-6 (IL6 ), and decreased levels of the anti-inflammatory adipokine adiponectin [5], independent of obesity $[5,6]$. Moreover, infusion of insulin in humans not change concentrations of the inflammatory cytokines TNF- $\alpha$, IL-1 $\beta$, IL- 6 and IL-8, or of hsCRP. Effects on vascular endothelial growth factor (VEGF) - which may positively relate to insulin resistance, and on chemerin and leptin adipokines related to obesity, and obesity-related pathologies, were also studied. At $\mathrm{t}=60 \mathrm{~h}, \mathrm{VEGF}$ concentrations were significantly increased during the fasted period $(\mathrm{p}<0.05)$. At the same time point, chemerin $(p<0.01)$ and leptin $(p<0.01)$ were significantly decreased after fasting. For leptin, this decrease was also significant after $36 \mathrm{~h}(\mathrm{p}<0.01)$. Adiponectin levels remained unchanged. In healthy young lean men, fastinginduced increases in FFAs leading to insulin resistance do not cause changes in concentrations of the inflammatory cytokines. VEGF concentrations increased and those of chemerin decreased.

increased leptin concentrations, which has also been linked to inflammation [7], and decreased adiponectin concentrations [8]. Finally, hyperglycemia can contribute to activation of NF-kB [9]. Thus, a complex interplay exists between FFA concentrations, insulin resistance, and inflammation. Further, it is unknown if insulin resistance per se is more important than hyperinsulinemia or hyperglycemia to explain the effects on inflammation.

Recently, we have shown that in lean healthy men prolonged fasting ( $60 \mathrm{~h}$ ) was accompanied by elevated plasma FFA levels and reduced insulin sensitivity [10]. Importantly, fasting-induced insulin resistance was not accompanied by hyperinsulinemia or hyperglycemia, which makes it possible to study the effects of physiologically increased FFA concentrations apart from those of increased insulin and glucose concentrations on 
Table 1 Subject characteristics.

\begin{tabular}{|l|l|}
\hline Parameter & Mean \pm SEM \\
\hline Age (years) & $23.3 \pm 0.8$ \\
\hline Body weight $(\mathrm{kg})$ & $79.6 \pm 2.5$ \\
\hline Fat free mass $(\mathrm{kg})$ & $66.6 \pm 2.0$ \\
\hline Height $(\mathrm{m})$ & $1.87 \pm 0.03$ \\
\hline Body mass index $\left(\mathrm{kg} / \mathrm{m}^{2}\right)$ & $22.8 \pm 0.5$ \\
\hline Maximal aerobic capacity $\left(\mathrm{ml} \mathrm{O}_{2} / \mathrm{kg}_{\mathrm{FFM}} / \mathrm{min}\right)$ & $57.8 \pm 1.6$ \\
\hline Values refer to 10 male subjects & \\
\hline
\end{tabular}

inflammatory markers. Therefore, the aim of the present study was to examine effects of FFA and insulin resistance, without the presence of increased glucose and insulin concentrations, on plasma biomarkers related to low-grade systemic inflammation and on plasma adipokines. Effects on vascular endothelial growth factor (VEGF) - which may positively relate to insulin resistance [11], and on chemerin - an adipokine related to obesity, and obesity-related pathologies [12], whose synthesis may be affected by TNF- $\alpha$ [13], were also studied.

\section{Methods}

$\nabla$

\section{Subjects}

Eleven healthy lean male volunteers without family history of diabetes mellitus or any other endocrine disorder participated in this study ( 0 Table 1 ). None of the subjects engaged in sports activities for more than $2 \mathrm{~h}$ per week. Body composition and maximal aerobic capacity were measured as described previously [10]. The study protocol was reviewed and approved by the Medical Ethical Committee of Maastricht University Medical Center and all subjects gave their written informed consent before participating in the study.

\section{Experimental design}

Using a randomized crossover design with a 2-week wash-out period, subjects participated in 2 experimental periods: a $60-\mathrm{h}$ fast and a 60-h normal fed condition. In the fast condition, subjects were fasted for $60 \mathrm{~h}$ (calorie-free drinks only), while in the other condition diets were adjusted individually to match energy expenditure (50,35, $15 \%$ of energy as carbohydrates, fat, and protein, respectively) [14]. Before the start of each experimental period, a standardized evening meal was provided. Subject stayed in a respiration chamber during the entire 60 -h period to ensure compliance to the strict dietary protocols and to allow for the measurement of 24-h substrate oxidation and energy expenditure. In the respiration chamber subjects followed an activity protocol as previously described $[15,16]$. Sleep as such was not monitored, but movements were $[14,15]$. During each 60 -h period, blood samples were taken after 12,36 , and $60 \mathrm{~h}-$ after an overnight fast of $10 \mathrm{~h}$ in the case of the fed condition.

\section{Hyperinsulinemic-euglycemic clamp}

After leaving the respiration chamber on the morning of the third day, a hyperinsulinemic-euglycemic clamp procedure was performed, as described [10].

\section{Blood analyses}

Blood was collected in EDTA containing tubes and immediately centrifuged at high speed. Plasma was transferred to Eppendorf tubes, snap frozen in liquid nitrogen, and stored at $-80{ }^{\circ} \mathrm{C}$ until further analysis. Plasma FFAs (Wako Nefa C test kit; Wako Chemicals, Neuss, Germany) and glucose (hexokinase method; LaRoche, Basel, Switzerland) were measured with enzymatic assays. Insulin was determined using a radioimmunoassay (Linco Research, St. Charles, MO, USA).

Plasma markers of inflammation (TNF- $\alpha$ (tumor necrosis factoralpha), IL-1 $\beta$, IL-6, IL-8 and hs-CRP) were measured with a commercially available Multi Spot ELISA kit (Meso Scale Discovery, Gaithersburg, MD, USA). ELISA kits for leptin, adiponectin, and chemerin analyses were purchased from Biovendor (Heidelberg, Germany) and those for VEGF from Millipore (Schwalbach, Germany). All samples for one subject were analyzed in the same analytical run. The intra- and interassay coefficients of variation (CV) varied slightly for the various measurements, but were all less than $<5 \%$ and $<7 \%$, respectively.

\section{Statistics}

Data are reported as means \pm SEM. Statistical analyses were performed using SPSS 16.0 for Mac OS X. Statistical comparisons between the 2 conditions (fed vs. fast) were performed using the paired Student's $t$-test. Plasma parameters over time were compared by 2-way repeated measures ANOVA for investigation of treatment and time (treatment $\times$ time) interactions. When the interaction reached statistical significance, we performed posthoc testing to determine the exact location of the difference. Differences were considered statistically significant when $\mathrm{p}<0.05$.

\section{Results \\ $\nabla$}

Results of one subject were removed from the statistical analysis, because of a hs-CRP concentration at the start of the fed period $>50 \mathrm{mg} / \mathrm{dl}$, as opposed to a value of $<1 \mathrm{mg} / \mathrm{dl}$ at the start of the fasted period. Characteristics of the remaining 10 subjects are presented in - Table 1 . Results on insulin sensitivity have been described in detail previously [10]. In summary, the glucose infusion rate for all subjects was decreased after the 60-h fasted period as compared with the fed period. Also the insulin sensitivity index $\left(\mathrm{S}_{\mathrm{I}}\right)$ was reduced by $\sim 45 \%(\mathrm{p}<0.001)$. The reduction in whole body insulin sensitivity was mainly accounted for by a reduction in insulin-stimulated glucose disposal. Insulin-induced suppression of endogenous glucose production was only marginally affected by fasting and was almost complete in both conditions. During the stay in the respiration chamber, body weight decreased by $0.3 \pm 0.4 \mathrm{~kg}$ during the fed period and by $-1.2 \pm 0.2 \mathrm{~kg}$ during the fasted period ( $\odot$ Table 2 ).

\section{Blood parameters}

Concentrations of all parameters were not significantly different at the start of the fed and fasted periods.

A significant treatment $\times$ time interaction $(\mathrm{p}<0.001)$ was observed for plasma FFAs, glucose, and insulin concentrations [10]. Plasma FFA increased steadily, up to $2016 \pm 118 \mu \mathrm{mol} / \mathrm{l}$ in de fasted condition vs. $421 \pm 39 \mu \mathrm{mol} / \mathrm{l}$ in the fed condition ( $\mathrm{p}<0.001$ for the difference in changes). Plasma glucose values remained unchanged throughout the fed condition, but gradually decreased to $3.73 \pm 0.15 \mathrm{mmol} / \mathrm{l}$ after $60 \mathrm{~h}$ of fasting $(\mathrm{p}<0.001)$. Baseline plasma insulin levels did not change in the fed condition, but were markedly reduced in the fast condition to $7.3 \pm 0.7 \mu \mathrm{U} / \mathrm{ml}$ at $\mathrm{t}=36 \mathrm{~h}(\mathrm{p}<0.001)$ and were maintained at this lower level $(7.0 \pm 0.89 \mu \mathrm{U} / \mathrm{ml})$ at $\mathrm{t}=60 \mathrm{~h}(\mathrm{p}<0.001)$. 
Table 2 Effects of fasting on plasma markers of inflammation, VEGF, chemerin, leptin, and adiponectin.

\begin{tabular}{|c|c|c|c|c|c|c|c|}
\hline \multirow[b]{2}{*}{$n=10$} & \multicolumn{3}{|l|}{ Fed period } & \multicolumn{3}{|c|}{ Fasted period } & \multirow{2}{*}{$\begin{array}{l}\mathrm{p} \text {-Value } \\
\text { Treatment } \times \text { Time interaction }\end{array}$} \\
\hline & $t=2 h$ & $t=36 h$ & $t=60 h$ & $t=12 h$ & $t=36 h$ & $t=60 h$ & \\
\hline TNF- $\alpha$ (pg/ml) & $4.33 \pm 0.34$ & $4.70 \pm 0.26$ & $4.43 \pm 0.35$ & $4.94 \pm 0.38$ & $4.87 \pm 0.32$ & $4.48 \pm 0.30$ & 0.156 \\
\hline Changes & & $0.37 \pm 0.19$ & $0.10 \pm 0.30$ & & $-0.07 \pm 0.18$ & $-0.46 \pm 0.21$ & \\
\hline IL-1 $(p g / m l)$ & $0.79 \pm 0.25$ & $0.84 \pm 0.26$ & $0.71 \pm 0.17$ & $0.90 \pm 0.21$ & $0.81 \pm 0.16$ & $2.02 \pm 0.67$ & 0.288 \\
\hline Changes & & $0.05 \pm 0.25$ & $-0.08 \pm 0.23$ & & $-0.09 \pm 0.23$ & $1.12 \pm 0.55$ & \\
\hline IL-6 (pg/ml) & $0.62 \pm 0.08$ & $0.60 \pm 0.05$ & $0.57 \pm 0.04$ & $0.87 \pm 0.17$ & $0.66 \pm 0.06$ & $0.96 \pm 0.14$ & 0.038 \\
\hline Changes & & $-0.02 \pm 0.07$ & $-0.05 \pm 0.08$ & & $-0.21 \pm 0.14$ & $0.09 \pm 0.22$ & \\
\hline IL-8 (pg/ml) & $2.73 \pm 0.30$ & $2.87 \pm 0.32$ & $2.75 \pm 0.27$ & $3.82 \pm 0.97$ & $3.10 \pm 0.42$ & $3.01 \pm 0.20$ & 0.310 \\
\hline Changes & & $0.14 \pm 0.35$ & $0.02 \pm 0.41$ & & $-0.72 \pm 0.73$ & $-0.81 \pm 0.89$ & \\
\hline hs-CRP (mg/dl) & $0.51 \pm 0.17$ & $0.43 \pm 0.18$ & $0.32 \pm 0.12$ & $0.97 \pm 0.55$ & $1.23 \pm 0.67$ & $1.39 \pm 0.56$ & 0.405 \\
\hline Changes & & $-0.07 \pm 0.05$ & $-0.19 \pm 0.06$ & & $0.26 \pm 0.53$ & $0.42 \pm 0.46$ & \\
\hline VEGF (pg/ml) & $18.6 \pm 7.7$ & $17.4 \pm 7.6$ & $81.8 \pm 11.2^{*}$ & $25.5 \pm 9.3$ & $40.7 \pm 15.5$ & $134.3 \pm 12.1$ & 0.042 \\
\hline Changes & & $-1.2 \pm 4.7$ & $63.2 \pm 10.1^{*}$ & & $15.2 \pm 16.5$ & $108.8 \pm 14.5$ & \\
\hline Chemerin (ng/ml) & $129 \pm 12$ & $120 \pm 8$ & $135 \pm 8$ & $114 \pm 7$ & $112 \pm 7$ & $88 \pm 6$ & 0.002 \\
\hline Changes & & $-8.1 \pm 7.5$ & $6.1 \pm 8.7^{+}$ & & $-2.5 \pm 3.5$ & $-26.5 \pm 3.8$ & \\
\hline Leptin (ng/ml) & $4.02 \pm 1.19$ & $3.91 \pm 1.32$ & $3.80 \pm 1.07$ & $3.89 \pm 0.85$ & $0.75 \pm 0.23$ & $0.19 \pm 0.08$ & 0.003 \\
\hline Changes & & $-0.10 \pm 0.33^{+}$ & $-0.22 \pm 0.29^{+}$ & & $-3.14 \pm 0.63$ & $-3.70 \pm 0.84$ & \\
\hline Adiponectin $(\mu \mathrm{g} / \mathrm{ml})$ & $8.41 \pm 0.44$ & $8.34 \pm 0.38$ & $8.41 \pm 0.50$ & $8.40 \pm 0.37$ & $8.29 \pm 0.46$ & $8.35 \pm 0.36$ & 0.991 \\
\hline Changes & & $-0.07 \pm 0.35$ & $0.00 \pm 0.31$ & & $-0.12 \pm 0.28$ & $-0.05 \pm 0.21$ & \\
\hline
\end{tabular}

VEGF concentrations could not be measured in one subject due to analytical problems.

${ }^{*} p<0.05$ and ${ }^{+} p<0.01$ indicate a statistically significant difference from the change at the same time point during the fasted period

Plasma TNF- $\alpha$ concentrations did not significantly change during the fasted or fed condition. Similar conclusions could be drawn for IL-1 $\beta$, IL-8, adiponectin, and hs-CRP. For IL-6, however, a statistically significant treatment $\times$ time effect was found $(\mathrm{p}=0.038)$, but pair wise comparisons did not reveal any statistical differences between the various time points.

A statistically significant treatment $\times$ time effect was found for VEGF concentrations $(p=0.042)$. No differences were seen after $36 \mathrm{~h}$. After $60 \mathrm{~h}$, however, concentrations were increased with $63.2 \pm 10.1 \mathrm{pg} / \mathrm{ml}$ during the fed period, which was significantly less than the increase of $108.8 \pm 14.5 \mathrm{pg} / \mathrm{ml}$ during the fasted period $(p=0.02)$. The treatment $\times$ time effect also reached statistical significance for changes in chemerin concentrations $(p=0.002)$. In the fed condition, concentrations remained virtually unaffected, but were significantly decreased after $60 \mathrm{~h}$ of fasting $(p=0.003)$. Leptin concentrations were also affected and were significantly decreased after 36 and 60 h of fasting ( $p=0.004$ and $\mathrm{p}<0.001$, respectively).

\section{Discussion}

$\nabla$

In the present study we have found that fasting-induced increases in FFA concentrations did not relate to changes in the concentrations of the inflammatory cytokines TNF- $\alpha$, IL-1 $\beta$, IL-6 and IL-8, or of hs-CRP. This extends the findings of a smaller study with 6 healthy lean men, that also found no proinflammatory effects of $60 \mathrm{~h}$ of fasting, as indicated by unchanged concentrations of IL-6, soluble TNF receptors I and II, and hs-CRP [17]. In our study, FFA concentrations were physiologically increased by fasting, which was accompanied by insulin resistance at reduced glucose and insulin concentrations [10]. In contrast, insulin resistance induced by longer-term lipid infusion does lead to hyperglycemia and hyperinsulinemia, and to increased concentrations of FFA and proinflammatory cytokines. This suggests that in normal weight men, insulin-resistance or increased FFA concentrations per se are not a prerequisite to induce a proinflammatory cytokine profile, but hyperglycemia or hyperinsulinemia - possibly in combination with high FFA levels - are. As prediabetic subjects, who are characterized by normal glucose concentrations and slightly elevated insulin concentrations, also have increased concentrations of markers and mediators of inflammation [18], it can be speculated that insulin may be more important in this respect. This is further supported by the findings of Stegenga et al. [19], who found that a short-term (6 h) lower-insulinemic hyperglycemic clamp decreased the expression of several proinflammatory cytokine in LPS-stimulated leucocytes. In contrast, after a hyperinsulinemic euglycemic clamp, expressions of most of the inflammatory cytokines were increased.

VEGF concentrations increased significantly during both conditions at $\mathrm{t}=60 \mathrm{~h}$ for which we do not have an obvious explanation. Concentrations, however, were significantly more increased in the fasted situation. The association between insulin and glucose concentrations on VEGF is not clear. Loebig et al. [20] could not demonstrate a relationship between VEGF concentrations and the insulin sensitivity index, as measured under euglycemic clamp conditions in lean, overweight or obese male subjects. In contrast, Dandona et al. [21] found suppressed VEGF concentrations during insulin infusion and steady glucose concentrations. Hypoglycemia, however, may also increase plasma VEGF concentrations, as suggested by in vitro and in vivo studies [22-24]. In addition, a positive correlation between concentrations of circulating VEGF levels and BMI has been reported in healthy male subjects [20]. As BMI is also positively related to FFA concentrations [25], it can be speculated that fasting also increases plasma VEGF. In vitro, FFAs induce a significant release of VEGF from vascular smooth muscle cells that might contribute to increased circulating levels of this factor [26]. Thus, although insulin sensitivity per se does not relate to VEGF, further studies are needed on the exact determinants of plasma VEGF levels.

Chemerin concentrations decreased after fasting. In vitro, chemerin synthesis and secretion by 3T3-L1 adipocytes are upregulated by TNF- $\alpha$ [13]. Furthermore, we have shown a regu- 
lation by TNF- $\alpha$ in human adipocytes [27]. Similar results have been found for IL-1 $\beta$ [28]. However, these 2 cytokines in our study were not affected by fasting and can therefore not have played a role in the decrease of plasma chemerin concentrations. Also, in vitro studies and studies in tissue explants have shown that insulin increases dose-and-time dependently chemerin secretion by adipocytes [29]. Further, a study in subjects with normal glucose tolerance has found positive relationships between plasma chemerin concentrations and various measures of the metabolic syndrome, although chemerin were not different between subjects with type 2 diabetes mellitus and controls [12]. At least for healthy subjects, this may suggest that insulin concentrations are an important determinant of plasma chemerin. To what extent plasma FFA concentrations play a role, is not known. It should be noted that the liver also secretes chemerin [30]. However, nothing is known about a possible regulation of hepatic chemerin release.

During fasting, plasma leptin levels decreased as expected [31], which was already evident after $24 \mathrm{~h}$. Adiponectin concentrations were not affected by fasting, which agrees with other study in which subjects fasted for 48 or $72 \mathrm{~h}[31,32]$. These findings support the notion that circulating adiponectin concentrations observed after weight reduction do not result from a negative energy balance, but rather from a decreased body fat content [32].

In conclusion, our study with healthy male subjects indicates that fasting-induced increases in FFAs and insulin resistance do not lead to changes in concentrations of the inflammatory cytokines. VEGF concentrations increased and those of chemerin decreased.

\section{Conflict of Interest \\ $\checkmark$}

The authors do not have any conflict of interest.

\section{References}

1 Tripathy D, Mohanty P, Dhindsa S, Syed T, Ghanim H, Aljada A, Dandona $P$. Elevation of free fatty acids induces inflammation and impairs vascular reactivity in healthy subjects. Diabetes 2003; 52: 2882-2887

2 Ford ES, Ajani UA, Mokdad AH. The metabolic syndrome and concentrations of $C$ reactive protein among U.S. youth. Diabetes Care 2005; 28: $878-881$

3 Ridker PM, Stampfer MJ, Rifai N. Novel risk factors for systemic atherosclerosis: a comparison of C-reactive protein, fibrinogen, homocysteine, lipoprotein(a), and standard cholesterol screening as predictors of peripheral arterial disease. JAMA 2001; 285: 2481-2485

4 Frohlich M, Imhof A, Berg G, Hutchinson WL, Pepys MB, Boeing H, Muche $R$, Brenner $H$, Koenig $W$. Association between C-reactive protein and features of the metabolic syndrome: a population-based study. Diabetes Care 2000; 23: 1835-1839

5 Abbasi F, Chu JW, Lamendola C, McLaughlin T, Hayden J, Reaven GM, Reaven PD. Discrimination between obesity and insulin resistance in the relationship with adiponectin. Diabetes 2004; 53: 585-590

6 McLaughlin T, Abbasi F, Lamendola C, Liang L, Reaven G, Schaaf P, Reaven $P$. Differentiation between obesity and insulin resistance in the association with C-reactive protein. Circulation 2002; 106: 2908-2912

7 Saad MF, Khan A, Sharma A, Michael R, Riad-Gabriel MG, Boyadjian R, Jinagouda SD, Steil GM, Kamdar V. Physiological insulinemia acutely modulates plasma leptin. Diabetes 1998; 47: 544-549

8 Yu JG, Javorschi S, Hevener AL, Kruszynska YT, Norman RA, Sinha M, Olefsky JM. The effect of thiazolidinediones on plasma adiponectin levels in normal, obese, and type 2 diabetic subjects. Diabetes 2002; 51: $2968-2974$
9 Schwartz EA, Reaven PD. Molecular and signaling mechanisms of atherosclerosis in insulin resistance. Endocrinol Metab Clin North Am 2006; 35: 525-549 viii

10 Hoeks J, van Herpen NA, Mensink M, Moonen-Kornips E, van Beurden $D$, Hesselink MK, Schrauwen P. Prolonged fasting identifies skeletal muscle mitochondrial dysfunction as consequence rather than cause of human insulin resistance. Diabetes 2010; 59: 2117-2125

11 Sandhofer A, Tatarczyk T, Kirchmair R, Iglseder B, Paulweber B, Patsch $J R$, Schratzberger $P$. Are plasma VEGF and its soluble receptor sFlt-1 atherogenic risk factors? Cross-sectional data from the SAPHIR study. Atherosclerosis 2009; 206: 265-269

12 Bozaoglu K, Bolton K, McMillan J, Zimmet P, Jowett J, Collier G, Walder $K$, Segal $D$. Chemerin is a novel adipokine associated with obesity and metabolic syndrome. Endocrinology 2007; 148: 4687-4694

13 Parlee SD, Ernst MC, Muruganandan S, Sinal CJ, Goralski KB. Serum chemerin levels vary with time of day and are modified by obesity and tumor necrosis factor-\{alpha\}. Endocrinology 2010; 151: 2590-2602

14 Schrauwen P, van Marken Lichtenbelt WD, Westerterp KR. Energy balance in a respiration chamber: individual adjustment of energy intake to energy expenditure. Int J Obes Relat Metab Disord 1997; 21: 769-774

15 Schoffelen PF, Westerterp KR, Saris WH, Ten Hoor F. A dual-respiration chamber system with automated calibration. J Appl Physiol 1997; 83: 2064-2072

16 Schrauwen $P$, van Marken Lichtenbelt WD, Saris WH, Westerterp KR. Changes in fat oxidation in response to a high-fat diet. Am J Clin Nutr 1997; 66: 276-282

17 van der Crabben SN, Allick G, Ackermans MT, Endert E, Romijn JA, Sauerwein HP. Prolonged fasting induces peripheral insulin resistance, which is not ameliorated by high dose salicylate. J Clin Endocrinol Metab 2008; 93: 638-641

18 Pickup JC, Crook MA. Is Type II diabetes mellitus a disease of the innate immune system? Diabetologia 1998; 41: 1241-1248

19 Stegenga ME, van der Crabben SN, Dessing MC, Pater JM, Van Den Pangaart PS, De Vos AF, Tanck MW, Roos D, Sauerwein HP, Van Der Poll T. Effect of acute hyperglycaemia and/or hyperinsulinaemia on proinflammatory gene expression, cytokine production and neutrophil function in humans. Diabetic Medicine 2008; 25: 157-164

20 Loebig M, Klement J, Schmoller A, Betz S, Heuck N, Schweiger U, Peters $A$, Schultes B, Oltmanns KM. Evidence for a relationship between VEGF and BMI independent of insulin sensitivity by glucose clamp procedure in a homogenous group healthy young men. PLoS One 2010; 5: e12610

21 Dandona P, Aljada A, Mohanty P, Ghanim H, Bandyopadhyay A, Chaudhuri $A$. Insulin suppresses plasma concentration of vascular endothelial growth factor and matrix metalloproteinase-9. Diabetes Care 2003; 26: 3310-3314

22 Sone H, Kawakami Y, Okuda Y, Kondo S, Hanatani M, Suzuki H, Yamashita $K$. Vascular endothelial growth factor is induced by long-term high glucose concentration and up regulated by acute glucose deprivation in cultured bovine retinal pigmented epithelial cells. Biochem Biophys Res Commun 1996; 221: 193-198

23 Merl V, Peters A, Oltmanns KM, Kern W, Hubold C, Fehm HL, Born J, Schultes $B$. Antecedent hypoglycaemia attenuates vascular endothelial growth factor response to subsequent hypoglycaemia in healthy men. Diabet Med 2005; 22: 1278-1281

24 Dantz D, Bewersdorf J, Fruehwald-Schultes B, Kern W, Jelkmann W, Born J, Fehm HL, Peters A. Vascular endothelial growth factor: a novel endocrine defensive response to hypoglycemia. J Clin Endocrinol Metab 2002; 87: 835-840

25 Boden G. Pathogenesis of type 2 diabetes. Insulin resistance. Endocrinol Metab Clin North Am 2001; 30: 801-815 v

26 Lamers D, Schlich R, Greulich S, Sasson S, Sell H, Eckel J. Oleic acid and adipokines synergize in inducing proliferation and inflammatory signaling in human vascular smooth muscle cells. J Cell Mol Med 2011; 15: 1177-1188

27 Sell H, Laurencikiene J, Taube A, Eckardt K, Cramer A, Horrighs A, Arner P, Eckel J. Chemerin is a novel adipocyte-derived factor inducing insulin resistance in primary human skeletal muscle cells. Diabetes 2009; 58: 2731-2740

28 Kralisch S, Weise S, Sommer G, Lipfert J, Lossner U, Bluher M, Stumvoll M, Fasshauer M. Interleukin-1beta induces the novel adipokine chemerin in adipocytes in vitro. Regul Pept 2009; 154: 102-106 
29 Tan BK, Chen J, Farhatullah S, Adya R, Kaur J, Heutling D, Lewandowski KC, O'Hare JP, Lehnert H, Randeva HS. Insulin and metformin regulate circulating and adipose tissue chemerin. Diabetes 2009; 58 : 1971-1977

30 Weigert J, Neumeier M, Wanninger J, Bauer S, Farkas S, Scherer MN, Schnitzbauer A, Schaffler A, Aslanidis C, Scholmerich J, Buechler C. Serum galectin-3 is elevated in obesity and negatively correlates with glycosylated hemoglobin in type 2 diabetes. J Clin Endocrinol Metab 2010; 95: 1404-1411
31 Merl V, Peters A, Oltmanns KM, Kern W, Born J, Fehm HL, Schultes B. Serum adiponectin concentrations during a 72-h fast in over- and normal-weight humans. Int J Obes (Lond) 2005; 29: 998-1001

32 Gavrila A, Chan JL, Yiannakouris N, Kontogianni M, Miller LC, Orlova C, Mantzoros CS. Serum adiponectin levels are inversely associated with overall and central fat distribution but are not directly regulated by acute fasting or leptin administration in humans: cross sectional and interventional studies. J Clin Endocrinol Metab 2003; 88: 4823-4831 